\title{
脳卒中片麻痺患者における起き上がり所要時間と 空間知覚および体性感覚との関連性
}

\author{
Relation of Sitting Up Time with Space Perception and Somatosensory \\ in Hemiplegic Patients with Stroke
}

篠原 智行1,3) 内田 恵理2) 臼田 滋3)

\author{
TOMOYUKI SHINOHARA ${ }^{1,3)}$, ERI UCHIDA ${ }^{2)}$, SHIGERU USUDA ${ }^{3)}$ \\ 1) Center of Rehabilitation, Hidaka Hospital: 886 Nakao-machi, Takasaki, Gunma 370-0001, Japan. TEL +81 27-362-6201 \\ 2) General Care Center, Heisei Hidaka Clinic \\ 3) Course of Health Sciences, Graduate School of Medicine, Gunma University
}

Rigakuryoho Kagaku 22(3): 413-417, 2007. Submitted Feb. 26, 2007. Accepted Apr. 17, 2007.

\begin{abstract}
The purpose of this study was to clarify wherher sitting up of hemiplegic patients with stroke had a relation with space perception or somatosensory. Subjects were 26 hemiplegic patients after stroke (mean age 64.0) and were assessed in the time to rise from supine to sitting and in functions by the wooden blocks test of the Wechsler Adult Intelligence Scale-Revised, sensory tests and abdominal power test of the Stroke Impairment Assessment Scale, Brunnstrom stage, trunk range of motion and Hasegawa's Dementia Scale-Revised. Assessment of sitting up time had high reliability $(\operatorname{ICC}(1,1)=0.86)$. Minimum time and average time on sitting up had significantly negative correlations with the block test and sensory tests. This finding suggests that sitting up of hemiplegic patients after stroke is related to space perception and somatosensory.
\end{abstract}

Key words: hemiplegia, sitting up, space perception

要旨: 起き上がりは空間内での運動の切り替えが多く, 空間知覚や体性感覚と関連していると考えられる。そこで脳 卒中片麻痺患者26名を対象に起き上がり所要時間, Wechsler Adult Intelligence Scale-Revisedの積み木テスト, Stroke Impairment Assessment Scaleの感覚および腹筋力テスト, Brunnstrom stage, 体幹可動域, 改訂長谷川式簡易知能評価ス ケールを評価し，これらの関連性について検討した。起き上がり所要時間測定の級内相関係数は 0.86 と高い信頼性が 得られた。起き上がり最小時間, 平均時間と積み木テストおよび感覚検查には有意な弱い負の相関が認められ, 起き 上がりと空間知覚および体性感覚との関連が示唆された。

キーワード : 脳卒中片麻痺患者, 起き上がり, 空間知覚

1) 日高病院リハビリテーションセンター：群馬県高崎市中尾町886（テ370-0001）TEL 027-362-6201

2) 平成日高クリニック総合ケアセンター 3) 群馬大学大学院 医学系研究科保健学専攻

受付日 2007年2月26日＼cjkstart受理日２007年4月17日 


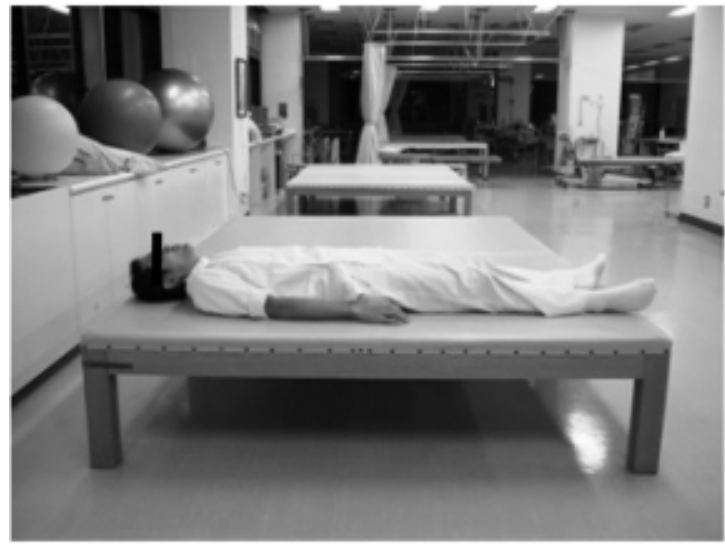

図1 開始肢位（左）と終了肢位（右）

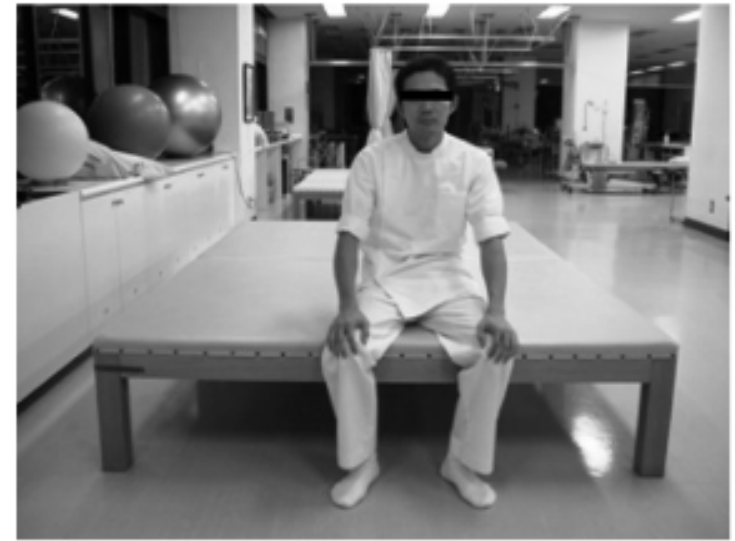

\section{I. はじめに}

起き上がりは日常生活動作の中で基本的かつ重要な 動作である。脳卒中片麻痺患者において立位や歩行は可 能だが, 起き上がりが困難であるという動作難易度順位 の逆転現象がみられることがある1)。高齢者でも歩行は できるが起き上がり自立度は低いことがある2)。片麻痺 患者の起き上がりは非麻痺側方向一寝返り, 半側臥位も しくは側臥位から片肘立て位となり端座位になる動作 手順が多い。そのため立ち上がりや歩行と比較すると起 き上がりは運動方向が単一ではなく, 空間内で様々な方 向への的確な運動の切り換えが必要である3)。このよう な起き上がりを円滑に遂行するには, 周囲の物体や環境 の三次元的構造を把握するための空間知覚や, 自己の運 動を制御するための体性感覚が必要と考えられる。

片麻痺患者の起き上がりについての検討は立ち上が りや歩行に比較すると少ない。起き上がりの定性的評価

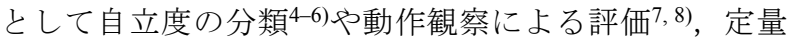
的評価として筋電図 ${ }^{9,10)}$, 所要時間の測定 $\left.7,8,11,12\right)$ など がある。

本研究の目的は片麻痺患者の起き上がり所要時間測 定の信頼性を検討するとともに, 起き上がり所要時間と 空間知覚および体性感覚との関連について検討するこ とである。また空間の情報は複数の感覚情報を統合して 知覚されると考えられることから, 空間知覚と体性感覚 の関連についても検討した。

\section{II. 対 象}

対象は口頭指示に従い起き上がりが監視または自立
である脳卒中片麻痺患者26名（男性14名, 女性12名）と した。なお半側空間無視を有する者は除外した。対象者 には測定の趣旨を説明し，同意書への記名を得た。平均 年齢は64.0歳（SD 11.3，33～85歳）, 右片麻痺13名, 左 片麻痺13名, 発症からの経過日数は478日（SD 1066, 19 〜3984日）であった。

\section{III. 方 法}

起き上がり所要時間はプラットホーム（縦 $180 \mathrm{~cm}$, 横 $135 \mathrm{~cm}$, 高さ $44.5 \mathrm{~cm})$ 上で, 最大速度にて背臥位から非 麻痺側へ起き上がり, 端座位に至るまでの時間をストッ プウォッチにて3回測定した。開始は検者の口頭指示に よる合図，終了は静的坐位姿勢（図1）とし，検者の合 図は統一した。計測毎の休㹮は被験者の疲労に合わせ任 意とした。また背臥位での枕の使用も任意とした。

空間知覚評価として, 視空間認知などを評価できる ${ }^{14)}$ Wechsler Adult Intelligence Scale-Revised (WAIS-R) の動作 性下位検査項目である積み木テスト（全10問，61点満 点）15)を実施した。積み木テストは複数の立方体を組み 合わせて, 提示された絵カードと同じ図形を制限時間内 に完成させる課題である。また体性感覚評価としてStroke Impairment Assessment Scale（SIAS）13)の上下肢表在およ び深部感覚検査を実施した。この感覚検査は全4項目で それぞれ0点から3点の4段階で評価される。さらにその 他の身体・精神機能としてBrunnstrom stage（Br.stage）, SIASの腹筋力検査, 端坐位での体幹屈曲 - 回旋可動域, 改訂長谷川式簡易知能評価スケール（HDS-R） 16）を計 測した。

統計処理にはSPSS11.0Jを使用した。起き上がり所要 
時間測定の検者内信頼性を検討するため全対象におけ るICC（1,1）を算出した。また検者間信頼性については 対象4名に対し3名の検者が測定した結果より ICC $(2,1)$ を算出した。起き上がり所要時間の指標は3回の最小時 間, 平均時間, および変動係数とし, 起き上がり所要時 間測定の整合性をみるためそれぞれPearsonの相関係数 を求めた。起き上がり所要時間の各指標と各測定項目に ついてはSpearmanの順位相関係数を求めた。さらに感覚 検査4項目が全て満点であった対象を感覚障害なし群, それ以外を感覚障害あり群とし, これら2群間の比較を 起き上がり所要時間では検定, 積み木テストではMannWhitneyのU検定にて行った。また感覚検查と積み木テ ストとのSpearmanの順位相関係数を求めた。有意水準は 全て $5 \%$ 未満とした。

\section{IV. 結 果}

1. 起き上がり所要時間計測の信頼性および整合性について 検者内信頼性はICC $(1,1)$ で0.86（95\%信頼区間0.75 -0.93），また検者間信頼性はICC $(2,1)$ で0.99（95\%信 頼区間0.98-0.99）と共に高い信頼性が得られた。

最小時間と平均時間には有意な高い相関を認めた $(\mathrm{r}=0.99, \mathrm{p}<0.01)$ 。しかし最小時間と変動係数の相関は $\mathrm{r}=0.18 （ \mathrm{p}=0.39 ）$, 平均時間と変動係数の相関は $\mathrm{r}=0.31$ $(\mathrm{p}=0.13)$ と有意な相関を認めなかった。

2. 起き上がり所要時間との関連について

測定結果を表1に示す。最小時間および平均時間と積 み木テスト, 上肢表在感覚, 下肢表在感覚, 下肢深部感 覚には有意な弱い負の相関が認められた（表2）。変動係 数は積み木テストのみ $\mathrm{r}_{\mathrm{s}}=0.43(\mathrm{p}<0.05)$ と有意な弱い負 の相関が認められた。その他の検查項目とは有意な相関 は認められなかった。

感覚障害なし群（14名）と感覚障害あり群（12名）の 群間比較では, 最小時間がそれぞれ3.3秒，5.6秒，平均 時間がそれぞれ3.8秒, 6.3 秒と共に有意差が認められた。 どちらも感覚障害なし群の方で時間が短い傾向にあっ た (表3)。

\section{3. 積み木テストと感覚検查について}

積み木テストと感覚検查の各項目には有意な相関は 認められなかった（表4）。

また積み木テスト得点の中央值は感覚障害なし群 (14 名）で25点, 感覚障害あり群（12名）で21点であり, 有 意差は認められなかった。
表1 測定結果

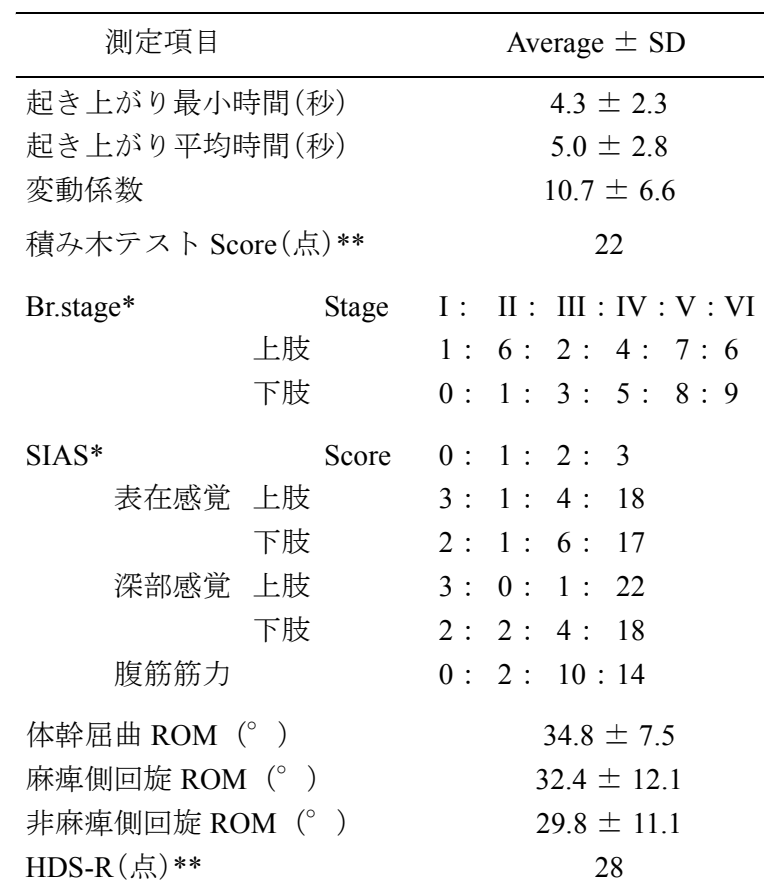

*Br.stage と SIAS については各評価の実数を表す

**積み木テストと HDS-R については中央値を表す

表2 起き上がり所要時間との相関係数

\begin{tabular}{llll}
\hline & 最小時間 & 平均時間 & 変動係数 \\
\hline 積み木テストScore & $-0.393^{*}$ & $-0.406^{*}$ & $-0.425^{*}$ \\
上肢表在感覚 & $-0.462^{*}$ & $-0.411^{*}$ & -0.130 \\
下肢表在感覚 & $-0.520^{* *}$ & $-0.461^{*}$ & 0.128 \\
上肢深部感覚 & -0.315 & -0.279 & 0.196 \\
下肢深部感覚 & $-0.436^{*}$ & $-0.405^{*}$ & 0.309 \\
上肢 Br.stage & -0.178 & -0.156 & 0.021 \\
下肢 Br.stage & -0.064 & -0.029 & 0.044 \\
腹筋筋力 & -0.314 & -0.305 & 0.037 \\
体幹屈曲 ROM & -0.066 & -0.151 & -0.316 \\
麻痺側回旋 ROM & -0.124 & -0.197 & -0.095 \\
非麻痺側回旋 ROM & -0.056 & -0.117 & -0.017 \\
HDS-R & -0.145 & -0.196 & -0.278 \\
\hline
\end{tabular}

Spearman の順位相関係数, $* *: p<0.01, *: p<0.05$

表3 感覚障害による比較

\begin{tabular}{lrrr}
\hline & 感覚障害なし & 感覚障害あり & \multicolumn{1}{c}{$\mathrm{p}$ 值 } \\
\hline 最小時間 (秒) & $3.3 \pm 1.5$ & $5.6 \pm 2.5$ & $\mathrm{p}<0.05$ \\
平均時間 $($ 秒 $)$ & $3.8 \pm 1.6$ & $6.3 \pm 3.1$ & $\mathrm{p}<0.05$ \\
変動係数 & $11.0 \pm 4.0$ & $10.4 \pm 8.6$ & $\mathrm{p}=0.84$ \\
\hline
\end{tabular}

(Average $\pm \mathrm{SD})$ 
表4 積み木テストと感覚検査の相関係数

\begin{tabular}{lcccc}
\hline & 上肢表在感覚 & 下肢表在感覚 & 上肢深部感覚 & 下肢深部感覚 \\
\hline 積み木テスト Score & 0.215 & 0.204 & 0.175 & 0.002 \\
\hline
\end{tabular}

\section{V. 考 察}

起き上がり時間測定についてAlexanderら ${ }^{11)} に よ る と ，$ 高齢者を対象に至適速度での起き上がり所要時間測定 にて，一週間のTest-Retestの信頼性はICCで0.8であった としている。今回の起き上がり時間測定の検者内および 検者間信頼性もともに高い值を示し, 起き上がり時間測 定は信頼性の高い起き上がり評価の1つであると考えら れた。

3回の起き上がり所要時間の変動係数と最小時間およ び平均時間には相関が認められなかった。また変動係数 は積み木テストとのみ相関が認められ, 最小・平均時間 とは性質の異なる指標であると考えられた。変動係数は 動作の確実性が反映され, 実測值とは異なった身体機能 との関連を示すと考えられたが, その特徴については今 回の結果からは明らかにならなかった。一方, 最小時間 と平均時間には強い相関が認められ, 他の評価項目との 相関関係にも差異が少ないことから, どちらも同様な起 き上がり能力の指標と考えられた。

起き上がり時間と積み木テストには弱い負の相関が 認められた。筒井17)によると物体の三次元的構造や位置 の知覚には頭頂連合野が役割を担っているとされる。積 み木テストは頭頂連合野の機能が反映されると考えら れる。一方, 同じく頭頂連合野は空間内の運動と関連し ている可能性があり ${ }^{18)}$, またKalaska ${ }^{19,20)}$ らは関節の角度 やその時間的変化に関連があるとしている。よって空間 内で運動の切り換えが多い起き上がりも, 積み木テスト と同様に頭頂連合野が関与していると考えられる。以上 のことから積み木テストと起き上がりには相関が認め られたと考えられる。しかし, 起き上がりと頭頂連合野 との関連性を明らかにするには, 脳活動の検査を含めた 検討をする必要がある。

起き上がり時間は感覚検査とも相関が認められたが, 運動麻痺や可動域などの運動機能との相関は認められ なかった。起き上がりは運動機能より, 空間知覚や体性 感覚などによる運動調節機能が必要であることが示唆

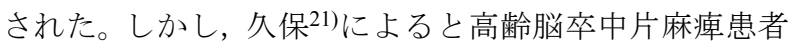
の起き上がりパターンには腹筋筋力が関与しており, 金 子ら ${ }^{22)}$ も高齢者の起き上がりには腹筋筋力が関与すると
している。これらはいずれも腹筋筋力を定量的に評価し ている。今回の腹筋力検査は4段階の順序尺度で表され ており, 腹筋力評価としての感度に問題があると思われ た。

積み木テストと感覚検査には関連がみられなかった。 これは, 空間知覚は体性感覚よりも視覚情報を中心とす る複数のモダリティーの情報が統合することによって 成り立っており 17,23), 体性感覚の影響は小さいためと考 えられた。

対象の脳卒中発症の経過日数のばらつきが大きかっ たのは, 今回の対象の取り込み基準に経過日数を定めて おらず, 多くは発症から半年以内であったが, 10年前後 経過した対象も数名いたためと考えられた。脳卒中の急 性期と慢性期では, 身体機能や動作学習の円熟さの違い などから起き上がりの特徵が異なる可能性があり, 考慮 する必要があった。

以上のことから，脳卒中片麻痺患者の起き上がりに おいて空間知覚や体性感覚との関連性が示唆された。し かしこれらの因果関係は明らかになっておらず, 今後は より定量的な評価を含めた検討を重ねていく必要があ る。

\section{引用文献}

1) 西田宗幹, 植松光俊, 金澤寿久 - 他 : 脳卒中片麻痺の基本動 作能力の難易度順位について. 理学療法科学, 1998, 13(2): 7378

2) 永原久栄: (超) 高齢者の日常生活動作. PTジャーナル, 1992, 26(1): 14-20.

3) 武内 朗: 片麻痺患者の寝返り・起き上がり動作獲得のため の加速的アプローチ. 理学療法, 2000, 17(12): 1074-1078.

4) Collin C, Wade D: Assessing motor impairment after stroke: a pilot reliability study. J Neurol Neurosurg Psychiatry, 1990, 53(7): 576-579.

5) Carr JH, Shepherd RB, Nordholm L, et al.: Investigation of a new motor assessment scale for stroke patients. Phys Ther, 1985, 65(2): 175-180.

6) 吉尾雅春, 糠野猛人, 橋詰尚明・他 : 片麻痺の頚・体幹 - 骨 盤の運動機能検査法の試作. 理・作・療法, 1980, 14(12): 831839.

7) Alexander NB, Fry-Welch DK, Ward ME, et al.: Quantitative assessment of bed rise difficulty in young and elderly women. J 
Am Geriatr Soc, 1992, 40(7): 685-691

8) Boffelli S, Franzoni S, Rozzini R, et al.: Assessment of functional ability with the bed rise difficulty scale in a group of elderly patients. Gerontology, 1996, 42(5): 294-300.

9) 西本勝夫, 小林 茂, 橋本 努・他 : 背臥位, 側臥位そして 腹臥位からの起き上がり動作における表面筋電図分析. 理学 療法学, 1989, 16(5) : 317-322.

10) 沖山 努, 嶋田智明, 吉田正樹 - 他: 片麻痺患者における起 き上がり動作の分析. 理学療法学, 1987, 14(4): 323-327.

11) Alexander NB, Galecki AT, Nyquist LV, et al.: Chair and bed rise performance in ADL-impaired congregate housing residents. J Am Geriatr Soc, 2000, 48(5): 526-533.

12) Alexander NB, Grunawalt JC, Carlos S, et al.: Bed mobility task performance in older adults. J Rehabil Res Dev, 2000, 37(5): 633638.

13) 千野直一: 脳卒中患者の機能評価 SIASとFIMの実際.シュ プリンガーフェアラーク，東京，1997.

14) 宮森孝史 : 総合的評価法一神経心理学的検査のす寸女方. 高 次脳機能障害のリハビリテーションVer. 2, 医歯薬出版, 東 京, 2004, pp152-158.

15) 品川不二郎, 小林重雄, 藤田和弘 - 他 : 日本版WAIS-R成人
知能検查法. 日本文化科学社, 東京, 1990, pp94-99.

16) 加藤信司, 下垣 光, 小野寺敦志 - 他 : 改訂長谷川簡易知能 評価スケール（HDS-R）の作成. 老年精神医学雑誌，1991， 2(11): 1339-1347.

17) 筒井健一郎 : 視覚の大脳整理 (頭頂葉) 一空間の知覚と認知 一. 神経進歩, 2004, 48(4): 186-194.

18) 小松英彦: 空間と運動の脳内表現. 科学, 1991, 61(4): 239-248.

19) Kalaska JF, Cohen DAD, Prud'homme M, et al.: Parietal area 5 Neuronal activity encodes movement kinematics, not movement dynamics. Exp Brain Res, 1990, 80(2): 351-364.

20) Kalaska JF, Cohen DAD, Hyde ML, et al.: A comparison of movement direction-related versus load direction-related activity in primate motor cortex, using a two-dimensional reaching task. J Neurosci, 1983, 9(6): 2080-2102.

21) 久保 晃: 高齢脳卒中片麻痺患者の起き上がりパターンと腹 筋筋力の関係. 理学療法科学, 1997, 12(2): 73-77.

22) 金子純一郎, 潮見泰藏, 黒澤和生 : 高齢者の起き上がり動作 と理学療法. 理学療法, 2003, 20(10): 1055-1061.

23) 三崎将也, 宮内 哲: 進む七下認知機能の解明. 脳 21,2002 , 5(4): 376-380. 